\title{
Genetic Variability Studies on Yield, Physiological and Nutritional Traits in Pearl Millet [Pennisetum glaucum (L.) R. Br.]
}

\author{
V. Priyanka ${ }^{1 *}$, P. Shanthi ${ }^{1}$, D.M. Reddy ${ }^{1}$ and B. Ravindra $\operatorname{Reddy}^{2}$ \\ ${ }^{1}$ Department of Genetics \& Plant Breeding, S.V. Agricultural College, Tirupati - 517501 , \\ Dist. Chittoor (Andhra Pradesh), India \\ ${ }^{2}$ Department of Statistics and Mathematics, S.V. Agricultural College, Tirupati - 517501 , \\ Dist. Chittoor (Andhra Pradesh), India \\ *Corresponding author
}

\section{A B S T R A C T}

Keywords

Variability,

Heritability,

Genetic advance,

Pearl millet

Article Info

Accepted:

07 June 2019

Available Online:

10 July 2019
Forty two genotypes of pearl millet were evaluated in randomized block design for twenty two physiological, nutritional and yield related traits to estimate genetic variability, heritability and genetic advance as a percentage of mean. The analysis of variance revealed significant variability for all the 22 yield, physiological and nutritional traits. Among the 22 characters studied, the genetic advance as percent of mean along with higher values of heritability, GCV and PCV estimates were maximum for grain yield plot $^{-1}$, green fodder yield plot $^{-1}$, iron content, leaf area duration, green fodder yield plant $^{-1}$ and zinc content indicating that the genetic variances for these traits are probably owing to their high additive gene effects.

\section{Introduction}

Pearl millet [Pennisetum glaucum (L.) R. Br.] belongs to the family poaceae (graminae) and genus Pennisetum. It is diploid $(2 \mathrm{x}=14)$ in nature and is commonly known as cattail millet or bulrush millet in English (Adam, 1996). It is the third most important cereal crop in India, after rice and wheat. It provides nutritionally superior and staple food for millions of people living in harsh environments characterised by erratic rainfall and nutrient-poor soils (Lakshmana, 2008).
The grain has high levels of protein $(12-15 \%)$ content with balanced amino acids, carbohydrates $(60-70 \%)$, calcium, phosphorus, iron, zinc and fats (5-10\%) which are important in the human diet compared to other major cereal crops (Devos et al., 2006). It has more oil than maize and is a "high-energy" cereal. In areas growing pearl millet, $35 \%$ of total consumption of energy, protein, iron and zinc is from this millet. It is found to be the economical source for rural residents to get micronutrients (Rao et al., 2006). However, the stable expression of these nutrients is required for the benefit of mankind in terms of 
nutritional security. Health wise, pearl millet is recommended for people suffering from celiac disease and diabetes. It is highly effective and recommended in cases of severe constipation and stomach ulcers. It helps in lowering cholesterol levels and is associated with bringing down the risk of cancer as well as supporting weight loss. Green fodder is more palatable because it does not have $\mathrm{HCN}$ (hydrogen cyanide) content as that of sorghum (Lakshmana, 2008). Therefore, there is an immediate need to breed stable pearl millet cultivars with high yielding coupled with better nutritional quality.

To initiate such breeding programme aiming for varietal improvement, the knowledge of genetic variability existing among different genotypes is a prerequisite. The nature and extent of variability forms the basis for all crop improvement programmes. Estimation of genetic variability in conjuction with the estimates of heritability and genetic advance indicates the possible improvement achieved through selection. The degree of success depends on the magnitude of heritability which measures the relative amount of the heritable portion of total variation and aids in selection. Similarly, genetic advance (GA) under selection gives an idea about how much of the genetic gain was obtained due to selection. Hence, the estimates of genetic variability, heritability and genetic advance will be of immense value in selection and breeding for high yielding hybrids coupled with quality.

\section{Materials and Methods}

Forty two genotypes of pearl millet were grown in a randomized block design with three replications during kharif, 2018 at Sri Venkateswara Agricultural College dry land farm, Tirupati. Each genotype was sown in one row of $3 \mathrm{~m}$ length with a spacing of $50 \mathrm{~cm}$ between rows and $12 \mathrm{~cm}$ between plants within the row. The data were recorded on five competitive plants taken from each replication for plant height, no. of productive tillers plant $^{-1}$, panicle length, panicle girth, 1000 - grain weight, grain yield plant $^{-1}$, grain yield plot $^{-1}$, green fodder yield plant ${ }^{-1}$, green fodder yield plot $^{-1}$, specific leaf area at 40 DAS, specific leaf area at 60 DAS, SPAD chlorophyll meter reading at 40 DAS, SPAD chlorophyll meter reading at $60 \mathrm{DAS}$, leaf area index at 40 DAS, leaf area index at 60 DAS, leaf area duration, harvest index, iron content, zinc content and protein content. The characters viz., days to $50 \%$ flowering and days to maturity were recorded on per plot basis. Means were computed and data were analysed for variances and coefficient of variation as suggested by Burton (1952) and heritability (broad sense) as the ratio of genotypic to phenotypic variance. The procedure of Johnson et al., (1955) was followed for calculating the expected genetic advance and genetic advance as per cent of mean.

\section{Results and Discussion}

In the present study the analysis of variance revealed highly significant differences for all the twenty two characters studied among the genotypes, indicating a good deal of variation among forty two genotypes of pearl millet (Table 1). Maximum range of variation was observed for green fodder yield plot $^{-1}$ followed by grain yield plot $^{-1}$, plant height, Leaf Area Duration, harvest index, iron content and grain yield plant $^{-1}$.

The perusal of the mean performance, the genotypes ICHiFe-1, ATP-11, ATP-13, ATP8, ATP-16, ATP-3, ATP-9, ATP-5, АTP-15 and ATP-7 have recorded desirable mean performance for most of the yield and physiological traits, while, ICHiFe-18, ICHiFe-19, ICHiFe-17, ICHiFe-13, ICHiFe-3, ICHiFe-21, ATP-2 and ATP-12 have 
displayed the maximum per se performance for the most of the nutritional traits. Hence these genotypes can be utilized for breeding of nutritionally rich genotypes with high grain and fodder yields.

Table.1 Analysis of variance for 22 characters in 42 genotypes of pearl millet

\begin{tabular}{|c|c|c|c|c|}
\hline \multirow[t]{2}{*}{ S. No. } & \multirow[t]{2}{*}{ Character } & \multicolumn{3}{|c|}{ Mean sum of squares } \\
\hline & & $\begin{array}{l}\text { Replications } \\
\text { (Df:2) }\end{array}$ & $\begin{array}{l}\text { Treatments } \\
\text { (Df:41) }\end{array}$ & $\begin{array}{c}\text { Error } \\
\text { (Df:82) }\end{array}$ \\
\hline 1 & Days to $50 \%$ flowering (days) & 4.264 & $40.264 * *$ & 7.843 \\
\hline 2 & Days to maturity (days) & 1.881 & $201.860^{* *}$ & 4.328 \\
\hline 3 & Plant height $(\mathrm{cm})$ & 110.393 & $1955.559 * *$ & 41.026 \\
\hline 4 & No. of productive tillers plant ${ }^{-1}$ (no.) & $0.226^{*}$ & $1.723^{* *}$ & 0.073 \\
\hline 5 & Panicle length $(\mathrm{cm})$ & 6.409 & $61.544 * *$ & 2.662 \\
\hline 6 & Panicle girth $(\mathrm{cm})$ & 0.140 & $0.534 * *$ & 0.049 \\
\hline 7 & 1000 - grain weight $(\mathrm{g})$ & 2.819 & $26.243 * *$ & 0.911 \\
\hline 8 & Grain yield plant ${ }^{-1}(\mathrm{~g})$ & 24.182 & $174.527 * *$ & 8.122 \\
\hline 9 & Grain yield $\operatorname{plot}^{-1}\left(\mathrm{~kg} \mathrm{ha}^{-1}\right)$ & 111189.900 & $2456549.210^{* *}$ & 82398.769 \\
\hline 10 & Green fodder yield plant ${ }^{-1}(\mathrm{~kg})$ & 0.001 & $0.003^{* *}$ & 0.0001 \\
\hline 11 & Green fodder yield plot $^{-1}\left(\mathrm{~kg} \mathrm{ha}^{-1}\right)$ & 12960540.000 & $112612558.060 * *$ & 4919245.187 \\
\hline 12 & Specific Leaf Area at 40 DAS $\left(\mathrm{cm}^{2} \mathrm{~g}^{-1}\right)$ & 100.175 & $550.923 * *$ & 168.192 \\
\hline 13 & Specific Leaf Area at 60 DAS $\left(\mathrm{cm}^{2} \mathrm{~g}^{-1}\right)$ & 993.502 & $2416.524 * *$ & 6.014 \\
\hline 14 & SCMR at 40 DAS & 48.461 & $59.926 * *$ & 19.207 \\
\hline 15 & SCMR at 60 DAS & 113.910* & $50.607 * *$ & 16.175 \\
\hline 16 & Leaf Area Index at 40 DAS & $0.0313^{*}$ & $0.399 * *$ & 0.006 \\
\hline 17 & Leaf Area Index at 60 DAS & $0.060 * *$ & $0.293 * *$ & 0.005 \\
\hline 18 & Leaf Area Duration $\left(\mathrm{cm}^{2} \mathrm{day}^{-1}\right)$ & 15881.200 & $183156.306^{* *}$ & 9842.901 \\
\hline 19 & Harvest Index (\%) & 18.382 & $142.866 * *$ & 6.111 \\
\hline 20 & Fe content (ppm) & 23.627 & $2220.503 * *$ & 26.903 \\
\hline 21 & Zn content $(\mathrm{ppm})$ & 11.595 & $178.330 * *$ & 5.807 \\
\hline 22 & Protein content $(\%)$ & 0.961 & $28.883 * *$ & 0.874 \\
\hline
\end{tabular}

* Significant at 5\% level, ** Significant at $1 \%$ level. 
Table.2 Mean, range, coefficients of variation, heritability (broad sense) and genetic advance as per cent of mean for yield attributing, physiological and nutritional characters in 42 pearl millet genotypes

\begin{tabular}{|c|c|c|c|c|c|c|c|c|c|c|c|}
\hline \multirow{2}{*}{$\begin{array}{l}\text { S. } \\
\text { No. }\end{array}$} & \multirow{2}{*}{ Character } & \multirow[t]{2}{*}{ Mean } & \multicolumn{2}{|c|}{ Range } & \multicolumn{2}{|c|}{ Variance } & \multicolumn{2}{|c|}{ Coefficient of variation } & \multirow{2}{*}{$\begin{array}{c}\text { Heritability } \\
\text { (broad } \\
\text { sense) } \\
(\%)\end{array}$} & \multirow{2}{*}{$\begin{array}{l}\text { Genetic } \\
\text { advance } \\
\text { (GA) }\end{array}$} & \multirow{2}{*}{$\begin{array}{c}\text { Genetic } \\
\text { advance as } \\
\text { percent of } \\
\text { mean }(\%)\end{array}$} \\
\hline & & & Min. & Max. & Genotypic & phenotypic & Genotypic & phenotypic & & & \\
\hline 1 & $\begin{array}{l}\text { Days to } 50 \% \\
\text { flowering }\end{array}$ & 49.04 & 38.33 & 57.33 & 10.81 & 18.65 & 6.70 & 8.81 & 57.95 & 5.16 & 10.51 \\
\hline 2 & $\begin{array}{l}\text { Days to } \\
\text { maturity }\end{array}$ & 88.02 & 72.00 & 104.00 & 65.84 & 70.17 & 9.22 & 9.52 & 93.83 & 16.19 & 18.40 \\
\hline 3 & $\begin{array}{l}\text { Plant height } \\
\text { (cm) }\end{array}$ & 122.96 & 72.60 & 183.77 & 638.18 & 679.20 & 20.55 & 21.20 & 93.96 & 50.44 & 41.03 \\
\hline 4 & $\begin{array}{l}\text { No. of } \\
\text { productive } \\
\text { tillers plant }\end{array}$ & 2.92 & 1.89 & 4.48 & 0.55 & 0.62 & 25.36 & 26.98 & 88.36 & 1.44 & 49.11 \\
\hline 5 & $\begin{array}{l}\text { Panicle length } \\
(\mathrm{cm})\end{array}$ & 21.47 & 13.38 & 36.77 & 19.63 & 22.29 & 20.63 & 21.99 & 88.06 & 8.56 & 39.89 \\
\hline 6 & $\begin{array}{l}\text { Panicle girth } \\
(\mathrm{cm})\end{array}$ & 3.55 & 2.76 & 4.40 & 0.16 & 0.21 & 11.38 & 12.98 & 76.91 & 0.73 & 20.56 \\
\hline 7 & $\begin{array}{l}1000 \text { - grain } \\
\text { weight }(\mathrm{g})\end{array}$ & 13.94 & 8.36 & 19.71 & 8.44 & 9.36 & 20.85 & 21.95 & 90.26 & 5.69 & 40.81 \\
\hline 8 & $\begin{array}{l}\text { Grain yield } \\
\text { plant }^{-1}(\mathrm{~g})\end{array}$ & 40.08 & 25.28 & 60.72 & 55.47 & 63.59 & 18.58 & 19.89 & 87.23 & 14.33 & 35.75 \\
\hline 9 & $\begin{array}{l}\text { Grain yield } \\
\text { plot }^{-1}\left(\mathrm{~kg} \mathrm{ha}^{-1}\right)\end{array}$ & 2699.31 & 1197.29 & 4814.14 & 791383.48 & 873782.25 & 32.96 & 34.63 & 90.57 & 1744.02 & 64.61 \\
\hline 10 & $\begin{array}{l}\text { Green fodder } \\
\text { yield plant }{ }^{-1} \\
(\mathrm{~kg})\end{array}$ & 0.11 & 0.03 & 0.17 & 0.0011 & 0.0012 & 28.98 & 30.49 & 90.34 & 0.06 & 56.74 \\
\hline
\end{tabular}


Table.2 Contd....

\begin{tabular}{|c|c|c|c|c|c|c|c|c|c|c|c|}
\hline 11 & $\begin{array}{l}\text { Green fodder } \\
\text { yield } \text { plot }^{-1}(\mathrm{~kg} \\
\left.\text { ha }^{-1}\right)\end{array}$ & 18679.31 & 8361.17 & 32586.71 & 35897770.96 & 40817016.15 & 32.08 & 34.20 & 87.95 & 11574.82 & 61.97 \\
\hline 12 & $\begin{array}{l}\text { Specific Leaf } \\
\text { Area at } 40 \text { DAS } \\
\left(\mathrm{cm}^{2} \mathrm{~g}^{-1}\right)\end{array}$ & 165.67 & 133.96 & 194.68 & 127.58 & 295.77 & 6.82 & 10.38 & 43.13 & 15.28 & 9.22 \\
\hline 13 & $\begin{array}{l}\text { Specific Leaf } \\
\text { Area at } 60 \text { DAS } \\
\left(\mathrm{cm}^{2} \mathrm{~g}^{-1}\right)\end{array}$ & 206.70 & 155.68 & 293.34 & 671.58 & 1073.37 & 12.54 & 15.85 & 62.57 & 42.23 & $20 . .43$ \\
\hline 14 & $\begin{array}{l}\text { SCMR at } 40 \\
\text { DAS }\end{array}$ & 44.70 & 33.23 & 54.42 & 13.57 & 32.78 & 8.24 & 12.81 & 41.41 & 4.88 & 10.93 \\
\hline 15 & $\begin{array}{l}\text { SCMR at } 60 \\
\text { DAS }\end{array}$ & 53.38 & 43.09 & 61.39 & 11.48 & 27.65 & 6.35 & 9.85 & 41.51 & 4.50 & 8.42 \\
\hline 16 & $\begin{array}{l}\text { Leaf Area Index } \\
\text { at } 40 \text { DAS }\end{array}$ & 1.26 & 0.61 & 2.02 & 0.131 & 0.136 & 28.61 & 29.22 & 95.85 & 0.73 & $\mathbf{5 7 . 7 0}$ \\
\hline 17 & $\begin{array}{l}\text { Leaf Area Index } \\
\text { at } 60 \text { DAS }\end{array}$ & 1.71 & 1.08 & 2.30 & 0.09 & 0.10 & 18.15 & 18.60 & 95.22 & 0.62 & 36.48 \\
\hline 18 & $\begin{array}{ll}\text { Leaf } & \text { Area } \\
\text { Duration } & \left(\mathrm{cm}^{2}\right. \\
\left.\text { day }^{-1}\right) & \end{array}$ & 819.81 & 349.55 & 1331.07 & 57771.14 & 67614.04 & 29.32 & 31.72 & 85.44 & 457.68 & 55.83 \\
\hline 19 & $\begin{array}{l}\text { Harvest Index } \\
(\%)\end{array}$ & 49.67 & 37.01 & 68.56 & 45.59 & 51.70 & 13.59 & 14.48 & 88.18 & 13.06 & 26.29 \\
\hline 20 & $\begin{array}{ll}\mathrm{Fe} & \text { content } \\
(\mathrm{ppm}) & \end{array}$ & 85.13 & 39.00 & 160.33 & 731.20 & 758.10 & 31.77 & 32.34 & 96.45 & 54.71 & 64.26 \\
\hline 21 & $\begin{array}{l}\mathrm{Zn} \\
(\mathrm{ppm})\end{array}$ & 26.43 & 15.00 & 46.00 & 57.51 & 63.31 & 28.69 & 30.11 & 90.83 & 14.89 & 56.33 \\
\hline 22 & $\begin{array}{l}\text { Protein content } \\
(\%)\end{array}$ & 12.44 & 9.15 & 20.85 & 9.34 & 10.21 & 24.56 & 25.69 & 91.44 & 6.02 & 48.39 \\
\hline
\end{tabular}


The results of variability, heritability and genetic advance as percentage of mean are presented in Table 2. In the present study, phenotypic co-efficient of variation was of high magnitude than the genotypic coefficient of variation for all the characters indicating the presence of influence of environment in the expression of these traits. The estimates of GCV and PCV were high for grain yield plot $^{-1}(\mathrm{GCV}=32.96 \% ; \mathrm{PCV}=$ $34.63 \%$ ) followed by green fodder yield plot $^{-1}$ $(\mathrm{GCV}=32.08 \% ; \mathrm{PCV}=34.20 \%)$, iron content $(\mathrm{GCV}=32.07 \% ; \mathrm{PCV}=32.68 \%)$, $\mathrm{LAD}(\mathrm{GCV}=29.32 \% ; \mathrm{PCV}=31.72 \%)$, green fodder yield plant ${ }^{-1}(\mathrm{GCV}=28.98 \%$; PCV = $30.49 \%)$, zinc content $(\mathrm{GCV}=28.69 \%$; PCV $=30.11 \%)$, LAI at 40 DAS $(\mathrm{GCV}=28.61 \%$; $\mathrm{PCV}=29.22 \%$ ), number of productive tillers plant $^{-1}(\mathrm{GCV}=25.36 \% ; \mathrm{PCV}=26.98 \%)$, protein content $(\mathrm{GCV}=24.56 \% ; \mathrm{PCV}=$ $25.69 \%)$, panicle length $(\mathrm{GCV}=20.63 \%$; $\mathrm{PCV}=21.99 \%), 1000$ grain weight $(\mathrm{GCV}=$ $20.85 \%$; PCV $=21.95 \%$ ) and plant height $(\mathrm{GCV}=20.63 \% ; \mathrm{PCV}=21.99 \%)$. Similar kind of estimates was also reported by Dehinwal et al., (2016) for green fodder yield plot $^{-1}$; Ravi et al., (2016) for. grain yield plot $^{-1}$ and green fodder yield plot $^{-1}$ and LAD; Anuradha et al., (2017) for number of productive tillers plant $^{-1}$, iron, zinc and protein content; Patel et al., (2018) for plant height; Sharma et al., (2018) for panicle length and Nehra et al., (2017) for green fodder yield plant $^{-1}$ and 1000 grain weight. Moderate co-efficient of variation was observed for grain yield plant ${ }^{-1}(\mathrm{GCV}=$ $18.58 \%$; PCV $=19.89 \%$ ) followed by LAI at 60 DAS $(\mathrm{GCV}=18.15 \% ; \mathrm{PCV}=18.60 \%)$, SLA at 60 DAS $(\mathrm{GCV}=12.54 \%$; $\mathrm{PCV}=$ $15.83 \%)$, harvest index $(\mathrm{GCV}=13.59 \%$; $\mathrm{PCV}$ $=14.48 \%)$ and panicle girth $(\mathrm{GCV}=11.38 \%$; PCV $=12.98 \%)$. Similar kind of estimates were also reported by Sumathi et al., (2010) and Bhasker et al., (2017) for grain yield plant $^{-1}$, Ravi et al., (2016) in pearl millet for harvest index and panicle girth and Patel et al., (2018) for panicle girth. On contrary, low estimate of co-efficient of variation was observed for the remaining characters viz., for $\mathrm{SCMR}$ at $60 \mathrm{DAS}(\mathrm{GCV}=6.35 \%$; $\mathrm{PCV}=$ $9.85 \%)$ followed by days to maturity $(\mathrm{GCV}=$ $9.22 \% ; \mathrm{PCV}=9.52 \%)$ and days to $50 \%$ flowering $(\mathrm{GCV}=6.70 \%$; $\mathrm{PCV}=8.81 \%)$. Similar kind of findings were also reported by Nehra et al., (2017) for days to $50 \%$ flowering; Ravi et al., (2016) for SCMR and days to maturity and Sharma et al., (2018) for days to flowering and days to maturity.

High heritability estimates were recorded for all the traits viz., iron content $(96.45 \%)$, LAI at 40 DAS $(95.85 \%)$, LAI at 60 DAS (95.22\%), plant height $(93.96 \%)$, days to maturity $(93.83 \%)$, protein content $(91.44 \%)$, zinc content $(90.83 \%)$, grain yield plot $^{-1}$ $(90.57 \%)$, green fodder yield plant ${ }^{-1}(90.34 \%)$, 1000 grain weight $(90.26 \%)$, number of productive tillers plant $^{-1}(88.36 \%)$, harvest index $(88.18 \%)$, panicle length $(88.06 \%)$, green fodder yield $\operatorname{plot}^{-1}(87.95 \%)$, grain yield plant $^{-1}(87.23 \%)$, LAD $(85.44 \%)$, panicle girth $(76.91 \%)$ and SLA at 60 DAS $(62.57 \%)$. Similar results were also observed by of Anuradha et al., (2017), Yaqoob (2015) and Govindaraj et al., (2010) for grain yield related traits and micronutrients and. Sharma et al., (2018) for number of productive tillers plant $^{-1}$, protein content and panicle girth. The high heritability observed for these traits in the present investigation indicated that the influence of environment on expression of these traits is relatively low. Therefore, for improving these traits the selection would be more effective in early generations on the basis of per se performance of these traits. These traits may be improved by mass or progeny selection.

The maximum genetic advance as per cent of mean was registered for green fodder yield plot $^{-1}$ (11574.82) followed by grain yield plot $^{-}$ (1744.02), LAD (25.31), iron content 
(54.71), plant height (50.44) and SLA at 60 DAS (42.23), Moderate genetic advance was observed for days to maturity (16.19), SLA at 40 DAS (15.28), zinc content (14.89), grain yield plant $^{-1}$ (14.33) and harvest index (13.06). These results were also in conformity with the findings of Dehinwal et al., (2016) for green fodder yield plot $^{-1}$ and Haq et al., (2015) for plant height.

In the present investigation, high heritability coupled with high genetic advance as per cent of mean was recorded for plant height, number of productive tillers plant ${ }^{-1}$, panicle length, panicle girth, 1000 - grain weight, grain yield plant $^{-1}$, grain yield plot $^{-1}$, green fodder yield plant ${ }^{-1}$, green fodder yield plot $^{-1}$, specific leaf area at 60 DAS, LAI at 40 DAS, LAI at 60 DAS, leaf area duration, harvest index, Fe content, $\mathrm{Zn}$ content and protein content indicating the preponderance of additive gene action and hence simple selection would be more effective for improvement of these characters. Similarly, high heritability coupled with moderate genetic advance as per cent of mean was recorded for days to maturity which might be controlled by both additive and non-additive gene effects. Recurrent selection would be more effective to improve this trait.

\section{References}

Adam M. A. 1996. Development of population diallel crosses of pearl millet elite composites. M.Sc. Thesis, University of Gesira Wad Medani, Sudan.

Anuradha, N., Tara Satyavathi, C., Meena, M. C., Mukesh Sankar, S., Bharadwaj, C., Bhat, J., Singh, O and Singh, S. P. 2017. Evaluation of pearl millet [Pennisetum glaucum (L.) R. Br.] for grain iron and zinc content in different agro climatic zones of India. Indian J. Genet., 77(1): 65-73.
Bhasker, K., Shashibushan, D., Krishna, K. M. and Bhave, M. H. V. 2017. Genetic Variability, Heritability and Genetic Advance of Grain Yield in Pearl Millet [Pennisetum glaucum (L.) R. Br.]. International Journal of Pure and Applied Bioscience. 5(4): 1228-1231.

Burton, G.W. 1952. Quantitative inheritance in grasses. Proceedings of $6^{\text {th }}$ Grass Land Congress Journal. 1: 277-278.

Dehinwal, A. K., Yadav, Y. P., Sivia, S. S and Kumar, A. 2016. Studies on Genetic Variability for Different Biometrical Traits in Pearl Millet [Pennisetum glaucum (L.) R. Br.]. An International Quarterly Journal of Life Sciences. 11(2):1023-1026.

Devos, K. M., Hanna, W. W and OziasAkins, P. 2006. Pearl millet. In: C. Kole (eds): Genome Mapping and Molecular Breeding in Plants, Vol. 1, Cereals and Millets. Springer-Verlag Berlin Heidelberg.

Govindaraj, M., Shanmugasundaram, $\mathrm{P}$ and Muthiah, A. R. 2010. Estimates of genetic parameters for yield and yield attributes in elite lines and popular cultivars of India's pearl millet. African Journal of Agricultural Research Vol. 5(22), pp. 3060-3064.

Haq, M. I., Khanum, S., Siddique, $M$ and Kamal, N. 2015. Correlation and Heritability Studies in Pearl Millet. International. Journal. Of Biology and Biotechnology. 12 (1): 81-83.

Johnson, H.W., Robinson, J.F and Comstock, R.E. 1955. Estimates of genetic and environmental variability in soybean. Agronomy Journal. 47: 314-318.

Lakshmana, D. 2008. Genetic diversity, heterosis and combining ability studies involving diverse sources of cytoplasmic genetic male sterility in pearl millet [Pennisetum glaucum (L.) R. Br]. PhD. Thesis, University of Agricultural Sciences, Dharwad. 
Nehra, M., Kumar, M., Kaushik, J., Vart, D., Sharma, R. K and Punia, M. S. 2017. Genetic Divergence, Character Association and Path Coefficient Analysis for Yield Attributing Traits in Pearl Millet [Pennisetum glaucum (L.) R. Br] Inbreds. Chemical Science Review and Letters. 2278-6783.

Patel, S. K., Gupta, S. K., Dangi, K. S., Sashibhushan, D., Balram, $\mathrm{M}$ and Ramesh, T. 2018. Panicle traits and plant height are important selection indices to enhance productivity in pearl millet (Pennisetum glaucum (L.) R. Br.) Populations. International Journal of Current Microbiology and Applied Sciences. 7(12): 306-312.

Rao, P., Birthal, P. S., Reddy, B. V. S., Rai, K. N and Ramesh, S. 2006. Diagnostics of sorghum and pearl millet grainsbased nutrition in India. International Sorghum and Millets Newsletter 46:9396.

Ravi, S., Subba Rao, Reddi Sekhar, M. 2016.
Character association and path coefficient analysis for yield and physiological traits in pearlmillet. Advances in Life Sciences. 5(19):86798683.

Sharma, B., Chugh, L. K., Sheoran, R. K., Singh, V. K and Sood, M. 2018. Study on genetic variability, heritability and correlation in pearl millets germplasm. Journal of Pharmacognosy and Phytochemistry. 7(6): 1983-1987.

Sumathi, P., Madineni, S and Veerabadhiran, P. 2010. Genetic variability for different biometrical traits in pearl millet genotypes (Pennisetum glaucum (L.) R. Br.). Electronic Journal of Plant Breeding. 1(4): 437-440.

Yaqoob, M. 2015. Genetic Component Analysis for Yield and Morphological Traits in Pearl Millet (Pennisetum glaucum (L.) R. Br.) Genotypes. Pakistan Journal of Scientific and Industrial Research. 58(3): 140-146.

\section{How to cite this article:}

Priyanka, V., P. Shanthi, D.M. Reddy and Ravindra Reddy, B. 2019. Genetic Variability Studies on Yield, Physiological and Nutritional Traits in Pearl Millet [Pennisetum glaucum (L.) R. Br.]. Int.J.Curr.Microbiol.App.Sci. 8(07): 501-508. doi: https://doi.org/10.20546/ijcmas.2019.807.061 